\title{
Productivity of Wheat as Influenced by Crop Residue and Potassium Management in Maize (Zea mays L.) - Wheat (Triticum aestivum L.) - Mungbean Cropping System
}

\author{
H.N. Meena*, K.S. Rana, Ashok Kumar, V. Pooniya, L. Shukla and D.R. Biswas
}

Indian Agricultural Research Institute, New Delhi-110 012, India

*Corresponding author

\begin{tabular}{|l|}
\hline Ke y w o r d s \\
Crop residue, \\
Fungal consortium, \\
KSB, DMA, LAI, \\
CGR, NAR and \\
yield
\end{tabular}

\section{Introduction}

Maize (Zea mays L.) is 'belongs to Poaceae family' one of the most important cereal crops in the world that maintain the world agricultural economy. It is also considered as a "Queen of Cereals". In India, maize is considered a promising option for diversifying agriculture in upland areas. Maize occupies an
A B S T R A C T

The field experiment was conducted at the 'Research farm' of Division of Agronomy, Indian Agricultural Research Institute, New Delhi, during 2014-15 and 2015-16 to study the growth parameter, yield and economies in maize-wheat-mungbean cropping system as influenced by crop residue and potassium management. The experiment consisted of 15 treatment combinations with three treatments in crop residue [no crop residue, Crop residue incorporation and fungal consortium incorporation and five treatments in recommended dose of potassium (RDK) $(\mathrm{K} \mathrm{kg} / \mathrm{ha})$, potassium management [control, $\mathrm{KSB}$, recommended dose of potassium $60 \mathrm{~kg} \mathrm{~K} / \mathrm{ha}, 50 \% \mathrm{RDK}+\mathrm{KSB}$ and $75 \% \mathrm{RDK}+\mathrm{KSB}]$. The wheat was positively influenced by variable crop residue and potassium management at growth stages during both the years. Results revealed that significantly highest plant height, DMA, LAI, mean crop growth rate, net assimilation rate, of wheat were noticed with treatment receiving fungal consortium incorporation which was statistically at par with crop residue incorporation. Similar results were also recorded for grain yield, straw yield and significant interaction grain yield in during 2014-15 and 2015-16 years. Further evaluation of revealed significantly improved due to $\mathrm{K}$ management practices during both years of experimentation. Potassium management in wheat of results revealed that significantly highest plant height, DMA, LAI, Mean crop growth rate, net assimilation rate, yield attributes, grain yield, straw yield of wheat were noticed with treatment receiving 100\% RDK+ KSB which were statistically at par with $75 \%$ RDK+ KSB. 
of $3093 \mathrm{~kg} \mathrm{ha}{ }^{-1}$ and is the second largest producer of wheat (93.5 million tonnes) after China in the world (Agricultural Statistic at Glance 2015). Current production is sufficient to meet the wheat demand of India, but the country has to increase annual wheat production from $93 \mathrm{Mt}$ at present to $105 \mathrm{Mt}$ by 2025 to meet the increasing demand (Prasad, 2011). Legumes are widely recognized as builders of soil fertility and contribute substantial amounts of $\mathrm{N}$ for sustainability of cereal-based cropping systems. The inclusion of legumes increases soil fertility and consequently the productivity of succeeding cereal crops (Ghosh et al., 2007). The inclusion of grain legumes was also beneficial for improving productivity, profitability, $\mathrm{N}$ economy and soil fertility in maize-wheat cropping system (Sharma et al., 2009).

It is estimated that about $686.2 \mathrm{mt}$ of crop residues are generated every year (Singh and Sidhu 2014). Out of this, about $234.4 \mathrm{mt}$ crop residue is available as surplus (Hiloidhari et al., 2014). Crop residues were natural resources with tremendous value to farmers and their use can be diversified as animal feed, composting, thatching for rural homes and fuel for domestic and industrial use. About 3040 percent of nitrogen, 25-30 of percent phosphorus, 30-40 percent of sulphur and 7580 percent of potassium uptake by cereal crops are retained in residues, making them valuable sources of nutrients (Singh and Sidhu 2014). The residue burning problem is severe in irrigated agriculture, particularly in the mechanized rice-wheat system. Crop residue incorporation in maize-based cropping system resulted in maximum growth and yield (Saha et al., 2010) and also improved soil properties by increasing productivity, protein yield, energy output, soil organic carbon (C), soil N, $\mathrm{P}$ and $\mathrm{K}$, population of bacteria, fungi, actinomycetes, microbial biomass, and $\mathrm{CO}_{2}$ evolution in soil (Sharma et al., 2010). Residue incorporation of the leguminous crop had a more beneficial effect on subsequent crop and also improves soil physical conditions (Manoj et al., 2009). The consortium of different hypercellulytic fungal culture can be used to lower $\mathrm{C} \mathrm{N}$ ratio of crop residue to quickly decomposable to avail nutrient at early stages of plant growth. The microbial consortium lignocellulolytic fungi can be used for rapid bio-conversion of agrowaste using organic inputs (ICAR NEWS., 2008).

\section{Materials and Methods}

The field experiment was conducted during 2014-15 and 2015-16 at 'Research Farm' of Division of Agronomy, Indian Agricultural Research Institute, New Delhi $\left(28.40^{\circ} \mathrm{N}\right.$ latitude, $77.12^{\circ} \mathrm{E}$ longitude and 228.6 MSL). The climate of Delhi is the subtropical and semi-arid type with hot and dry summer, cold winter and mild to heavy rainfall. It falls under the agro-climate zone 'Trans-Gangetic plains'. The mean annual rainfall of Delhi is $652 \mathrm{~mm}$ and more than $80 \%$ of that generally occurs during the monsoon season (JulySeptember) with the mean annual evaporation of $850 \mathrm{~mm}$. Weather conditions are attributed to have an impact on the performance of crops. Consequently, it becomes utmost important to take into consideration the conclusion from the experimental results. The minimum and maximum temperature ranged between $-0.9^{\circ}$ and $20.2^{\circ} \mathrm{C}$ and $0.5^{\circ}$ and $23.0^{\circ} \mathrm{C}$, with the rainfall of 315.8 and $19.8 \mathrm{~mm}$ during the growth period of wheat 2014-15 and 2015-16, respectively. The data showed that as compared to 2015-16, abnormally very high rainfall $(135.40 \mathrm{~mm})$ was received in January, February and March of 2014-15. The soil of experimental site was sandy loam with a bulk density of 1.48 and $1.46 \mathrm{mg} / \mathrm{m}^{3}$. In soil organic carbon was 0.46 and $0.52 \%$ with 158.4 and $164.2 \mathrm{~kg} / \mathrm{ha}$ available $\mathrm{N}, 14.45$ and $16.2 \mathrm{~kg} / \mathrm{ha}$ available $\mathrm{P}, 257.8$ and $268.5 \mathrm{~kg} / \mathrm{ha}$ available $\mathrm{K}$ in the first and second year, 
respectively. The $\mathrm{pH}$ was 8.14 and 7.9 with EC of 0.28 and $0.26 \mathrm{dS} / \mathrm{m}$ during 2014-15 and 2015-16 years, respectively. The experiment consisted of 15 treatment combinations with three treatments in crop residue [no crop residue, Crop residue incorporation and fungal consortium incorporation] and five treatments in recommended dose of potassium (RDK) (K $\mathrm{kg} / \mathrm{ha}$ ), potassium management [control, KSB, recommended dose of potassium $60 \mathrm{~kg} \mathrm{~K} / \mathrm{ha}$, $50 \% \mathrm{RDK}+\mathrm{KSB}$ and $75 \% \mathrm{RDK}+\mathrm{KSB}]$ was carried out in split plot design and replicated thrice. The required quantity of different requirements viz., Crop residue, fungal consortium incorporation and as per the treatments was applied in field ten days before sowing of both the crops. For studying the growth and yield attributes parameters of wheat five plants were tagged randomly in the second row of either side in the field. Dry matter accumulation (DMA) and leaf area studies were done from the randomly selected one meter from second-row wheat and the yield and yield attributes were record at harvest.

\section{Results and Discussion}

Application of residue and $\mathrm{K}$ management in different treatment combinations resulted in significant increase in growth parameters viz., plant height, dry matter accumulation (DMA) and leaf area index (LAI) over the control during both the years of experimentations (Table 1 and 3). The plant height under crop residue incorporation + fungal consortium was higher at all the stages compared to crop residue incorporation and no crop residue. The tallest plant height was observed with the application of $100 \%$ recommended a dose of potassium (RDK) all the growth stages during both the years of studies. However, 75\% RDK $+\mathrm{KSB}$ was at par with $100 \%$ RDK during both the years. Among the residue application treatment, crop residue + fungal consortium recorded highest dry matter accumulation
(1064.0 and $1080.2 \mathrm{~g} / \mathrm{m}^{2}$ ) at harvest stages as compared to rest of the treatment during first and second year respectively. The dry matter accumulation under crop residue incorporation was significantly higher harvest stages compared to no crop residue. At harvest, the maximum dry matter accumulation (1097.7 and $1112.2 \mathrm{~g} / \mathrm{m}^{-2}$ ) was observed with $100 \%$ RDK harvest growth stages and significant over to rest of the treatment during both the years. However, it was statistically at par with 75\% RDK+ KSB. Dry matter accumulation with $50 \% \mathrm{RDK}+\mathrm{KSB}$ and KSB significantly higher at all the stages compared to control during both years of study. As per the Borie et al., (2002) reported from Southern Chile in Andisol these organic amendments with Trichoderma virideae increased plant performance (growth attributes) and mineral acquisition (wheat more than lupine. The significantly higher leaf area index was noticed with crop residue + fungal consortium at 75 and 100 DAS but statistically at par with crop residue incorporation during both years. However, at early stage growth, leaf area index not affected significantly with crop residue management. Maximum leaf area index was recorded with crop residue + fungal consortium (4.47 and 4.56) while minimum leaf area index (4.27 and 4.35) was noted with no crop residue. $\mathrm{K}$ management practices considerably enhanced the leaf area index at different growth stages over control during both years of experimentation. Significantly highest leaf area index of 4.52 and 4.61 was noted during the first and second year of investigation respectively due to the application of $100 \%$ RDK as compared to rest of treatment but statistically at par with $75 \%$ RDK. As compared to the first year, maximum leaf area index was recorded in the second year of investigation. It might be due to residue application improved the physical condition of soil for better germination and seedling establishment (ICAR NEWS., 2008). Fungal consortium might have enhanced the 
availability and uptake of nutrients due to faster mineralization and release of nutrient at various crop growth stages, which in turn may increase the cell division and synthesis of photosynthates at the respective point of growth and development and due to a increased the activities of beneficial microorganisms due to increased organic pool in soil, which resulted in production of growth-promoting substances and improved nutrient availability for longer period throughout the crop growth (Gurdeep and Reddy, 2017)

\section{Crop growth indices}

The data in the table indicated that crop growth rate of wheat was positively influenced by variable crop residue and $\mathrm{K}$ application rates at all growth stages during both the years (Table 2 and 3) Maximum mean CGR was increased continuously due to crop residue management up to 75-100 DAS during both years of study and subsequently decreased it. Maximum CGR of 20.62 and $20.83 \mathrm{~g} / \mathrm{g} /$ day was observed with application of crop residue incorporation + fungal consortium significantly higher over no crop residue at all stages of wheat in both the year. Further evaluation of data in the same table revealed that CGR significantly improved due to $\mathrm{K}$ management practices during both years of experimentation. Among $\mathrm{K}$ management practices, significantly maximum CGR (21.46 and $21.67 \mathrm{~g} / \mathrm{m}^{2} /$ day) was recorded with $100 \%$ RDK at all growth stages over rest of the treatment but statically at par with $75 \%$ RDK + KSB.). A better soil physical condition provides more plant nutrients and source of energy for soil microbes. In crop residues on soil surface protect the soil against crusting and surface sealing, reduce soil compaction and temperature, conserve soil moisture, aggregation and macro-porosity and enhance root growth (Blanco- Canqui and Lal, 2006; Singh, 2011; Meena, 2015). It might be due to synergistic interaction of potassium with other nutrients which resulted in increased nutrient availability for photosynthetic activity in the plant. Baque et al., (2006) reported that uptake of $\mathrm{N}, \mathrm{P}$ and $\mathrm{K}$ were enhanced with increasing levels of $\mathrm{K}$. Higher rates of $\mathrm{K}$ allowed for the efficient use of more nitrogen, which resulted in better early vegetative growth (Anonymous, 1998). These results are also in close conformity with Juan et al., (2009) and Grzebisz et al., (2010) Xue et al., (2000) and Sheng et al., (2003).

A perusal of data presented in table showed that the Net Assimilation Rate (NAR) of wheat was positively influenced by variable residue and $\mathrm{K}$ application rates over control at all growth stages during both the years (Table 4). Significantly higher mean NGR was observed with application crop residue incorporation + fungal consortium over no crop residue at all stages of wheat in both the years. The maximum NAR (5.22 and 5.28 $\mathrm{g} / \mathrm{m}^{2} /$ day at $50-75 \mathrm{DAS}$ ) was recorded with crop residue incorporation + fungal consortium treatment followed by crop residue incorporation at all the stage of crop growth during 2014-15 and 2015-16. Among the different dose of potassium application, The maximum mean NAR $\left(5.24\right.$ and $5.29 \mathrm{~g} / \mathrm{m}^{2} /$ day at 50-75 DAS) was recorded with $100 \%$ RDK treatment followed by $75 \% \mathrm{RDK}+\mathrm{KSB}, 50 \%$ $\mathrm{RDK}+\mathrm{KSB}$ and KSB at all the stage of crop growth during 2014-15 and 2015-16. However, $100 \%$ RDK application significant as compared to rest of the treatment and it was statistically at par with $75 \% \mathrm{RDK}+\mathrm{KSB}$. It might be due to synergistic interaction of potassium with other nutrients which resulted in increased nutrient availability for photosynthetic activity in the plant. Baque et al., (2006) reported that uptake of N, P and K were enhanced with increasing levels of $\mathrm{K}$. Higher rates of $\mathrm{K}$ allowed for the efficient use of more nitrogen, which resulted in better early vegetative growth (Anonymous, 1998). 
Table.1 Effect of crop residue and potassium management on plant height at harvest and LAI of wheat

\begin{tabular}{|c|c|c|c|c|c|c|c|c|c|c|}
\hline \multirow[t]{3}{*}{ Treatments } & \multirow{2}{*}{\multicolumn{2}{|c|}{ Plant height }} & \multicolumn{8}{|c|}{ LAI } \\
\hline & & & \multicolumn{2}{|c|}{ 0-25 DAS } & \multicolumn{2}{|c|}{ 25-50 DAS } & \multicolumn{2}{|c|}{ 50-75 DAS } & \multicolumn{2}{|c|}{ 75-100 DAS } \\
\hline & 2014-15 & 2015-16 & 2014-15 & 2015-16 & 2014-15 & 2015-16 & 2014-15 & 2015-16 & 2014-15 & 2015-16 \\
\hline \multicolumn{11}{|l|}{ Residue management } \\
\hline No-crop residue & 96.45 & 98.66 & 0.211 & 0.216 & 2.30 & 2.34 & 3.49 & 3.56 & 4.27 & 4.35 \\
\hline Crop residue incorporation & 98.86 & 101.04 & 0.224 & 0.228 & 2.32 & 2.37 & 3.61 & 3.68 & 4.41 & 4.50 \\
\hline $\begin{array}{l}\text { Crop residue incorporation + fungal } \\
\text { consortium }\end{array}$ & 99.74 & 101.94 & 0.228 & 0.232 & 2.33 & 2.38 & 3.63 & 3.71 & 4.47 & 4.56 \\
\hline SEm \pm & 0.78 & 0.80 & 0.005 & 0.005 & 0.006 & 0.006 & 0.006 & 0.004 & 0.008 & 0.008 \\
\hline $\mathrm{CD}(\mathrm{P}=\mathbf{0 . 0 5})$ & NS & NS & NS & NS & 0.023 & 0.023 & 0.025 & 0.016 & 0.031 & 0.030 \\
\hline \multicolumn{11}{|l|}{ Potassium management } \\
\hline Control & 92.55 & 94.62 & 0.210 & 0.214 & 2.21 & 2.26 & 3.42 & 3.49 & 4.19 & 4.28 \\
\hline KSB & 96.09 & 98.24 & 0.215 & 0.220 & 2.25 & 2.30 & 3.49 & 3.55 & 4.28 & 4.37 \\
\hline $100 \%$ RDK (60 kg/ha) & 102.02 & 104.30 & 0.229 & 0.234 & 2.40 & 2.45 & 3.69 & 3.77 & 4.52 & 4.61 \\
\hline $50 \%$ RDK + KSB & 99.83 & 102.06 & 0.223 & 0.228 & 2.34 & 2.39 & 3.61 & 3.69 & 4.43 & 4.52 \\
\hline $75 \%$ RDK + KSB & 101.26 & 103.52 & 0.227 & 0.232 & 2.37 & 2.42 & 3.67 & 3.74 & 4.49 & 4.58 \\
\hline SEm \pm & 0.54 & 0.55 & 0.006 & 0.006 & 0.007 & 0.007 & 0.009 & 0.011 & 0.012 & 0.012 \\
\hline $\mathrm{CD}(\mathrm{P}=0.05)$ & 1.57 & 1.60 & NS & NS & 0.021 & 0.021 & 0.028 & 0.031 & 0.034 & 0.035 \\
\hline
\end{tabular}

Table.2 Effect of crop residue and potassium management on mean crop growth rate of wheat

\begin{tabular}{|c|c|c|c|c|c|c|c|c|c|c|}
\hline \multirow[t]{3}{*}{ Treatments } & \multicolumn{10}{|c|}{ Mean crop growth rate (g/day) } \\
\hline & \multicolumn{2}{|c|}{ 0-25 DAS } & \multicolumn{2}{|c|}{ 25-50 DAS } & \multicolumn{2}{|c|}{ 50-75 DAS } & \multicolumn{2}{|c|}{ 75-100 DAS } & \multicolumn{2}{|c|}{ 100-harvest } \\
\hline & 2014-15 & 2015-16 & 2014-15 & 2015-16 & 2014-15 & 2015-16 & 2014-15 & 2015-16 & 2014-15 & 2015-16 \\
\hline \multicolumn{11}{|l|}{ Residue management } \\
\hline No-crop residue & 1.275 & 1.288 & 4.27 & 4.31 & 14.52 & 14.67 & 19.15 & 19.34 & 0.760 & 0.768 \\
\hline Crop residue incorporation & 1.305 & 1.318 & 4.40 & 4.44 & 15.23 & 15.39 & 20.27 & 20.48 & 0.891 & 1.066 \\
\hline $\begin{array}{l}\text { Crop residue incorporation + fungal } \\
\text { consortium }\end{array}$ & 1.313 & 1.327 & 4.43 & 4.48 & 15.43 & 15.59 & 20.62 & 20.83 & 0.951 & 1.174 \\
\hline SEm \pm & 0.04 & 0.04 & 0.13 & 0.13 & 0.10 & 0.10 & 0.13 & 0.13 & 0.021 & 0.029 \\
\hline $\mathrm{CD}(\mathrm{P}=0.05)$ & 0.16 & 0.17 & 0.52 & 0.52 & 0.40 & 0.41 & 0.52 & 0.52 & 0.083 & 0.115 \\
\hline \multicolumn{11}{|l|}{ Potassium management } \\
\hline Control & 1.247 & 1.260 & 4.12 & 4.16 & 14.05 & 14.19 & 18.08 & 18.27 & 0.785 & 0.914 \\
\hline KSB & 1.275 & 1.288 & 4.26 & 4.30 & 14.62 & 14.77 & 19.24 & 19.43 & 0.837 & 0.973 \\
\hline $100 \%$ RDK (60 kg/ha) & 1.336 & 1.349 & 4.54 & 4.59 & 15.83 & 15.99 & 21.46 & 21.67 & 0.923 & 1.061 \\
\hline $50 \%$ RDK + KSB & 1.309 & 1.322 & 4.42 & 4.47 & 15.26 & 15.41 & 20.37 & 20.58 & 0.900 & 1.029 \\
\hline $75 \%$ RDK + KSB & 1.323 & 1.336 & 4.50 & 4.55 & 15.56 & 15.71 & 20.92 & 21.13 & 0.892 & 1.035 \\
\hline SEm \pm & 0.05 & 0.05 & 0.13 & 0.13 & 0.06 & 0.06 & 0.11 & 0.11 & 0.033 & 0.022 \\
\hline $\mathrm{CD}(\mathrm{P}=0.05)$ & 0.22 & 0.24 & 0.15 & 0.14 & 0.29 & 0.31 & 1.13 & 1.12 & 7.13 & 8.21 \\
\hline
\end{tabular}


Table.3 Effect of crop residue and potassium management on effective tiller, dry matter accumulation and yield net accumulation rate of wheat

\begin{tabular}{|c|c|c|c|c|c|c|c|c|c|c|}
\hline \multirow[t]{3}{*}{ Treatments } & \multirow{2}{*}{\multicolumn{2}{|c|}{ Effective tillers $/ \mathrm{m}^{2}$}} & \multirow{2}{*}{\multicolumn{2}{|c|}{ DMA }} & \multicolumn{6}{|c|}{ NAR } \\
\hline & & & & & \multicolumn{2}{|c|}{ 25-50 DAS } & \multicolumn{2}{|c|}{ 50-75 DAS } & \multicolumn{2}{|c|}{ 75-100 DAS } \\
\hline & 2014-15 & 2015-16 & 2014-15 & 2015-16 & 2014-15 & 2015-16 & 2014-15 & 2015-16 & 2014-15 & 2015-16 \\
\hline \multicolumn{11}{|l|}{ Residue management } \\
\hline No-crop residue & 357.67 & 364.27 & 995.8 & 1005.8 & 4.83 & 4.87 & 5.03 & 5.07 & 4.90 & 4.94 \\
\hline Crop residue incorporation & 363.87 & 370.60 & 1047.9 & 1062.8 & 4.86 & 4.91 & 5.17 & 5.22 & 5.02 & 5.07 \\
\hline $\begin{array}{l}\text { Crop residue incorporation + fungal } \\
\text { consortium }\end{array}$ & 367.07 & 373.27 & 1064.0 & 1080.2 & 4.87 & 4.95 & 5.22 & 5.28 & 5.06 & 5.12 \\
\hline SEm \pm & 1.26 & 0.48 & 4.3 & 4.3 & 0.02 & 0.02 & 0.05 & 0.04 & 0.03 & 0.03 \\
\hline $\mathrm{CD}(\mathrm{P}=0.05)$ & 4.95 & 1.88 & 16.8 & 17.0 & NS & NS & NS & NS & 0.12 & 0.12 \\
\hline \multicolumn{11}{|l|}{ Potassium management } \\
\hline Control & 351.44 & 357.44 & 953.2 & 965.8 & 4.80 & 4.84 & 5.02 & 5.07 & 4.72 & 4.77 \\
\hline KSB & 357.11 & 363.00 & 1001.5 & 1014.7 & 4.85 & 4.89 & 5.11 & 5.16 & 4.92 & 4.97 \\
\hline $100 \%$ RDK (60 kg/ha) & 371.67 & 379.33 & 1097.7 & 1112.2 & 4.89 & 4.95 & 5.24 & 5.29 & 5.19 & 5.24 \\
\hline 50\% RDK + KSB & 363.33 & 369.56 & 1052.0 & 1066.0 & 4.86 & 4.91 & 5.15 & 5.21 & 5.03 & 5.09 \\
\hline 75\% RDK + KSB & 370.78 & 377.56 & 1075.1 & 1089.3 & 4.87 & 4.92 & 5.18 & 5.23 & 5.10 & 5.15 \\
\hline SEm \pm & 1.17 & 1.30 & 3.2 & 3.2 & 0.02 & 0.02 & 0.03 & 0.02 & 0.03 & 0.03 \\
\hline $\mathrm{CD}(\mathrm{P}=0.05)$ & 3.42 & 3.80 & 9.3 & 9.4 & NS & NS & 0.07 & 0.07 & 0.09 & 0.10 \\
\hline
\end{tabular}

Table.4 Effect of crop residue and potassium management on yield attributes and yields of wheat

\begin{tabular}{|c|c|c|c|c|c|c|c|c|c|c|}
\hline \multirow[t]{2}{*}{ Treatments } & \multicolumn{2}{|c|}{ Spike weight (g) } & \multicolumn{2}{|c|}{ No. of grains spike ${ }^{-1}$} & \multicolumn{2}{|c|}{ Test weight (g) } & \multicolumn{2}{|c|}{ Grain yield ( $t / h a)$} & \multicolumn{2}{|c|}{ Straw yield ( $t / h a)$} \\
\hline & 2014-15 & 2015-16 & 2014-15 & 2015-16 & 2014-15 & 2015-16 & 2014-15 & 2015-16 & 2014-15 & 2015-16 \\
\hline \multicolumn{11}{|l|}{ Residue management } \\
\hline No-crop residue & 2.34 & 2.41 & 43.07 & 43.87 & 40.08 & 40.52 & 4.44 & 4.56 & 6.52 & 6.62 \\
\hline Crop residue incorporation & 2.62 & 2.79 & 44.60 & 45.20 & 40.32 & 41.34 & 5.10 & 5.26 & 6.65 & 6.78 \\
\hline $\begin{array}{l}\text { Crop residue incorporation + fungal } \\
\text { consortium }\end{array}$ & 2.82 & 3.13 & 45.13 & 46.47 & 41.34 & 43.81 & 5.25 & 5.43 & 6.79 & 6.93 \\
\hline SEm \pm & 0.07 & 0.06 & 0.38 & 0.13 & 0.35 & 0.54 & 0.03 & 0.04 & 0.04 & 0.04 \\
\hline $\mathrm{CD}(\mathrm{P}=0.05)$ & 0.26 & 0.22 & 1.49 & 0.51 & NS & 2.11 & 0.13 & 0.15 & 0.17 & 0.18 \\
\hline \multicolumn{11}{|l|}{ Potassium management } \\
\hline Control & 2.44 & 2.55 & 42.56 & 43.67 & 39.23 & 40.71 & 4.20 & 4.32 & 6.30 & 6.41 \\
\hline KSB & 2.58 & 2.69 & 43.67 & 44.33 & 39.58 & 41.13 & 4.36 & 4.49 & 6.58 & 6.70 \\
\hline $100 \%$ RDK (60 kg/ha) & 2.77 & 3.07 & 45.22 & 46.33 & 41.77 & 42.95 & 5.61 & 5.80 & 6.94 & 7.07 \\
\hline $50 \%$ RDK + KSB & 2.43 & 2.68 & 44.67 & 45.00 & 40.63 & 42.16 & 5.12 & 5.29 & 6.64 & 6.76 \\
\hline $75 \%$ RDK + KSB & 2.75 & 2.91 & 45.22 & 46.56 & 41.69 & 42.51 & 5.36 & 5.53 & 6.81 & 6.95 \\
\hline SEm \pm & 0.05 & 0.05 & 0.33 & 0.24 & 0.36 & 0.33 & 0.08 & 0.08 & 0.05 & 0.05 \\
\hline $\mathrm{CD}(\mathrm{P}=0.05)$ & 0.15 & 0.15 & 0.97 & 0.71 & 1.05 & 0.96 & 0.22 & 0.24 & 0.15 & 0.14 \\
\hline
\end{tabular}


Table.5 Interaction effect of crop residue and potassium management on yield of wheat during both years

\begin{tabular}{|c|c|c|c|c|c|c|}
\hline \multirow[t]{3}{*}{ Treatments } & \multicolumn{6}{|c|}{ Grain yield $\left(\mathrm{t} / \mathrm{ha}^{-1}\right)$} \\
\hline & \multicolumn{3}{|c|}{ 2014-15 } & \multicolumn{3}{|c|}{ 2015-16 } \\
\hline & $\begin{array}{l}\text { No crop } \\
\text { residue }\end{array}$ & $\begin{array}{l}\text { Crop residue } \\
\text { incorporation }\end{array}$ & $\begin{array}{c}\text { Crop residue } \\
\text { incorporation }+ \text { fungal } \\
\text { consortium }\end{array}$ & $\begin{array}{l}\text { No-crop } \\
\text { residue }\end{array}$ & $\begin{array}{l}\text { Crop residue } \\
\text { incorporation }\end{array}$ & $\begin{array}{c}\text { Crop residue } \\
\text { incorporation }+ \text { fungal } \\
\text { consortium }\end{array}$ \\
\hline Control & 4.11 & 4.17 & 4.32 & 4.21 & 4.30 & 4.45 \\
\hline KSB & 4.32 & 4.33 & 4.42 & 4.45 & 4.46 & 4.56 \\
\hline RDK & 4.82 & 5.87 & 6.15 & 4.97 & 6.05 & 6.38 \\
\hline $\begin{array}{l}\mathbf{5 0} \% \mathrm{RDK}+ \\
\mathrm{KSB}\end{array}$ & 4.43 & 5.43 & 5.49 & 4.54 & 5.60 & 5.73 \\
\hline $\begin{array}{l}75 \% \mathrm{RDK}+ \\
\mathrm{KSB}\end{array}$ & 4.50 & 5.72 & 5.85 & 4.64 & 5.90 & 6.06 \\
\hline SEm \pm & \multicolumn{3}{|c|}{0.17} & \multicolumn{3}{|c|}{0.18} \\
\hline $\mathrm{CD}(P=0.05)$ & \multicolumn{3}{|c|}{0.49} & \multicolumn{3}{|c|}{0.52} \\
\hline
\end{tabular}


These results are also in close conformity with Juan et al., (2009) and Grzebisz et al., (2010) Xue et al., (2000) and Sheng et al., (2003).

\section{Yield attributes and yield}

Data revealed that the application of residue and $\mathrm{K}$ management practices had a positive effect on different yield attributing parameter of wheat compared to its control. The maximum effective tiller, spike length and a number of grain/spike were recorded with crop residue + fungal consortium treatment during both years and significant over no crop residue. The lowest values of these attributes were observed with no crop residue. However, test weight was found nonsignificant during the first year. Further data showed that application of $100 \%$ RDK and $75 \% \mathrm{RDK}+\mathrm{KSB}$ was at par to each other found significant over rest of the treatments during both years into effective tillers, spike length, spike weight, number of grains/spike and test weight of wheat. However, application of $50 \%$ RDK + KSB was significantly superior over control and KSB treatment in all yield attributes during both years. The improvement in yield attributing character was due to the response of applied $\mathrm{K}$ as it is vital to many plant processes including photosynthesis, translocation of photosynthates, protein synthesis and activation of plant enzymes etc. Tabatabaii et al., (2011) also reported that application of K increased the number of grains/cob and 1000grain weight, grain number/row, grain weight/ row in maize. Polara et al., (2010) reported that $\mathrm{K}$ application at different doses significantly increased the number of tillers/ plant, number of grain/ spike. Seed inoculation with KSB increased the yield attributes of maize (Basavexsha et al., 2016) and wheat (Muralikaman, 1996). These findings are also conformity with Basavesha et al., (2016).
The data pertaining to grain yields and straw yield of the wheat crop are presented in table 4. The application of residue management practices and potassium management practices showed significant improvement in grain, straw and biological yield over control in wheat during both the years of experimentation. The treatment with crop residue incorporation + fungal consortium was significantly superior with respect to grain yield (5.25 and $5.43 \mathrm{t} / \mathrm{ha})$ in wheat as compared to no crop residue and crop residue incorporation during both years. However, crop residue incorporation was also recorded significant effect over no crop residue during both years. Maximum straw yield were noted with crop residue incorporation + fungal consortium but statistically at par with crop residue incorporation and significantly superior over no crop residue during both years of investigation. However, crop residue incorporation was found significant over no crop residue with respect to straw.

The consortium of different hypercellulytic fungal culture can be used to lower $\mathrm{C}$ : $\mathrm{N}$ ratio of crop residue to quickly decomposable to avail nutrient at early stages of plant growth. Bijay Singh et al., (2008) have concluded that application of rice residues to wheat with residue decomposing fungi typically has a small effect on wheat yields in short-term (1 to 3 years). Shafi et al., (2007) reported that crop residues incorporation significantly increased grain yield $(23.7 \%)$ of maize by as compared to residues removed treatment. Many researchers have reported the higher value of yield attributes under residue retention (Jat, 2010; Ram et al., 2010; Arif et al., 2011; Meena, 2015; Saad et al., 2015).

Further, data indicated that crop yields and harvest index of wheat were considerably affected by $\mathrm{K}$ management practiced during both years of experimentation. Application of $100 \%$ RDK showed significant superiority in 
grain yield of wheat (5.61 and $5.80 \mathrm{t} / \mathrm{ha}$ ) over all other treatment during both years of study. However, this significant superiority treatment was observed with $75 \%$ RDK + $\mathrm{KSB}, 50 \% \mathrm{RDK}+\mathrm{KSB}$ and KSB during both years over control. A similar trend was recorded of straw yield, maximum was recorded with $100 \%$ RDK during both years but it was statistically at par with $75 \%$ RDK + KSB. However, $50 \%$ RDK + KSB and KSB application were significantly superior to control during the period of testing. Mobilization of $\mathrm{K}$ from soil by bacterial strain through secretion of organic acids, protons, siderophores, exopolysaccharides and organic ligands, increased the availability of both essential macro and micronutrients for crop uptake in soil by maintaining good health of soil which might have resulted the improvement in the biomass yield (Basak and Biswas, 2009). Interaction effect of residue and $\mathrm{K}$-management practices on grain yield of wheat was found significant in both the years of experimentations (Table 5). The treatment with crop residue incorporation + fungal consortium and $100 \%$ RDK were significantly superior with respect to grain yield of wheat (6.15 and $6.38 \mathrm{t} / \mathrm{ha}$ ) as compared to no crop residue and control during both the year. Meena et al., (2016) also reported that microbial inoculants of potassium solubilising bacteria were able to dissolve $\mathrm{K}$ from mineral and rocks that enhanced plant growth and yield. Inoculation with KSMs have been reported to exert beneficial effects on growth of cotton and rape (Sheng, 2005), pepper and cucumber (Han et al., 2006), khella (Hassan et al., 2010), sorghum (Badar et al., 2006), wheat (Sheng and $\mathrm{He}, 2006$ ).

On the basis of the results illustrated by the present investigation, it can be concluded that growth parameter vis. DMA, LAI, Mean crop growth rate, and, net assimilation rate, of wheat, was noticed with treatment receiving fungal consortium incorporation which was statistically at par with Crop residue incorporation. Similar results were also recorded for grain yield and straw yield during 2014-15 and 2015-16 years. Further evaluation of revealed significantly improved due to $\mathrm{K}$ management practices during both years of experimentation. Potassium management in mungbean of results revealed that significantly highest plant height, DMA, LAI, Mean crop growth rate, net assimilation rate, yield attributes, grain yield, straw yield wheat were noticed with treatment receiving $100 \%$ RDK which were statistically at par with $75 \% \mathrm{RDK}+\mathrm{KSB}$. Interaction effect of residue and K-management practices, the treatment with crop residue incorporation + fungal consortium and $100 \%$ RDK were significantly superior with respect to grain yield of wheat as compared to no crop residue and control during both the year.

\section{References}

Agricultural Statistic at Glance (2016) Department of Agriculture, Cooperation and Farmers Welfare, Directorate of Economics and Statistics, Ministry of Agriculture \& Farmers Welfare, Government of India, pp 73-216.

Arif, M., Jan, M.T., Jamal, M.K., Saeed, M., Iqbal, M., Ziauddin, Habib A., Shahenshah and Khan, M.Z. 2011.Effect of cropping system and residue management on maize. Pakistan Journal of Botany 43 (2): 915-920.

Bagyalakshmi, B., Ponmurugan, P. and Marimuthu, S. (2012) Influence of potassium solubilizing bacteria on crop productivity and quality of tea (Camellia sinensis). African Journal of Agricultural Research 7, 4250-4259.

Baque, M.A., Karim, M.A., Hamid, A. and Tetsushi, H. 2006. Effects of fertilizer potassium on growth, yield and nutrient uptake of wheat (Triticum aestivum) under water stress conditions. South 
Pacific Studies 27 (1):25-35.

Basak, B.B. and Biswas, D.R. (2009) Influence of potassium solubilizing microorganism (Bacillus mucilaginosus) and waste mica on potassium uptake dynamics by sudangrass (Sorghum vulgare Pers.) grown under two Alfisols. Plant and Soil 317, 235-255.

Basavesha, K.N., Savalgi, V.P., Sreenivasa, M.N. and Manjunatha, H. 2016. Impact of bacteria solubilizing both potassium and phosphorus on growth and yield of maize (Zea mays L.). Research in Environment and Life Sciences 9(4):464-465.

Bijay-Singh, Shan, Y.H., Johnson-Beebout, S.E., Yadvinder Singh and Buresh, R.J. 2008. Crop residue management for lowland rice-based cropping systems in Asia. Advances in Agronomy 98: 201270.

Blanco-Canqui, H. and R. Lal. 2006. Impact of long-term wheat straw management on soil Hydraulic properties under notillage. Soil science society of America Journal 71: 1166 - 1173

Borie, A. k., Sharma, M.L. and Singh, S.P. 2002. Bio-degradation of Crop Residues by Trichoderma Species vis-a-vis Nutrient Quality of the Prepared Compost. Sugar Tech. 3 (7): 154-160.

Gathala-Mahesh, K., Kumar-Virender, Sharma, P. C., Saharawat-Yashpal, S., Jat, H. S., Singh Manipal, Kumar-Amit, Jat, M. L., Humphreys, E., Sharma, D. K., Sharma-Sheetal and Ladha, J. K. 2013. Optimizing intensive cereal-based cropping systems addressing current and future drivers of agricultural change in the northwestern Indo-Gangetic Plains of India. Agriculture, Ecosystems and Environment 177: 85-97.

Ghosh, P.K., Bandypadhyay, K.K., Wanjari, R.H., Manna, M.C., Mishra, A.K and Mohanty, M. 2007. Legume effect for enhancing productivity and nutrient use efficiency in major cropping systems an Indian perspective: a review. Journal of Sustainable Agriculture. 30(1):6186.

Grzebisz, W., Barlog, P., Szczepaniak, W. and Potarzycki, J. 2010. Effect of potassium fertilizing system on dynamics of dry matter accumulation by maize. Fertilizers and Fertilization 40: 57-69.

Han, H.S., Supanjani, E. and Lee, K.D. (2006) Effect of co-inoculation with phosphate and potassium solubilizing bacteria on mineral uptake and growth of pepper and cucumber. Plant Soil Environment 52(3), 130-136.

Hassan, E.A., Hassan, E.A. and Hamad, E.H. (2010) Microbial solubilization of phosphate-potassium rocks and their effect on khella (Ammi visnaga) growth. Annual Agricultural Sciences 55, 37-53.

Hiloidhari, M., Das, Dhiman and Baruah, D.C. (2014) Bioenergy potential from crop residue biomass in India. Renewable and Sustainable Energy Reviews, 32: 504-512.

ICAR NEWS, Microbial consortium for rapid bio-conversion of agro-waste using organic inputs. 2008.

Jat, N.K., Ashok, K. and Dhar, S. 2010. Influence of Sesbania green manure with or without wheat residues and $\mathrm{N}$ fertilization on maize (Zea mays)-wheat (Triticum aestivum) cropping system. Indian Journal of Agronomy 55 (4): 253-258.

Manoj Kumar., Jatav, M. K., Trehan, S. P. and Lal, S.S. 2009. Integrated Nutrient Management in Potato Based Cropping Systems For Eastern Indo-Gangetic Plains of India. Potato Journal. 36 (3 4): 136-142.

Meena, J.R., Behera, U.K., Chakraborty, D. and Sharma, A.R. 2015. Tillage and residue management effect on soil 
properties, crop performance and energy relations in green gram (Vigna radiata $\mathrm{L}$.) under maize-based cropping systems. International Soil and Water Conservation Research 3(4): 261-272.

Muralikannan, N. (1996) Biodissolution of silicate, phosphate and potassium by silicate solubilizing bacteria in rice ecosystem. M.Sc. (Ag) thesis submitted to Tamil Nadu Agricultural University, Coimbatore.p.125

Prasad, R. 2011. Nitrogen and food grain production in India. Indian Journal Fertilizer 7: 66-76.

Ram, H., Kler, D.S., Singh, Y. and Kumar, K. 2010. The productivity of maize (Zea mays) - wheat (Triticum aestivum) system under different tillage and crop establishment practices. Indian Journal of Agronomy 55 (3): 185-190.

Shafi, M., Bakht, J., Jan, M. T. and Shah, Z. 2007. Soil $\mathrm{C}$ and $\mathrm{N}$ dynamics and maize (Zea mays) yield as affected by cropping systems and residue management in north-western Pakistan. Soil and Tillage Research 94:520-527

Sharma, P., Vikas, A., Maruthi, G.R., Sankar, M. and Singh, B. 2009. Influence of tillage practices and mulching options on productivity, economics and soil physical properties of maize (Zea mays)-wheat (Triticum aestivum) system. Indian Journal of Agricultural Sciences 79 (11): 865-70.

Sheng, X. F. and He, L. Y., 2006. Solubilization of potassium bearing minerals by a wild type strain of
Bacillus edaphicus and its mutants and increased potassium uptake by wheat. Canadian Journal of Microbiology. 52(1): 66-72.

Sheng, X.F. (2005) Growth promotion and increased potassium uptake of cotton and rape by a potassium releasing strain of Bacillus edaphicus. Soil Biology and Biochemistry 37, 1918-1922.

Sheng, X.F., Xia, J.J. and Cheng, J. 2003. Mutagenesis of the Bacillus edaphicus strain NBT and its effect on growth of chilli and cotton. Agricultural Sciences in China 32: 258-265.

Singh, G., Sharma, G.L. and Golada S.L. 2011. Integrated nutrient management on quality protein maize (Zea mays L.).Journal of Progressive Agriculture 2 (3): $65-70$.

Singh, Y. and Sidhu, H.S. (2014) Management of cereal crop residues for a sustainable rice-wheat production system in the Indo-Gangetic plains of India. Proceedings of the Indian National Academy Sciences, 80: 95-114

Tabatabaii E.S., Yarnia M., Benam M.B.K. and Tabrizi E. F. M. 2011. Effect of Potassium fertilizer on corn yield under drought stress condition. AmericanEurasian Journal of Agriculture and Environment Science 10 (2): 257-263.

Xue, Q.H., Sheng, J.W. and Tang, L. 2000. Effect of $\mathrm{K}$ bacteria on nutrients activation in LouSoil Acta, Agriculture Boreali-Occidentalis. Sinica 9 (3): 6771.

\section{How to cite this article:}

Meena, H.N., K.S. Rana, Ashok Kumar, V. Pooniya, L. Shukla and Biswas, D.R. 2018. Productivity of Wheat as Influenced by Crop Residue and Potassium Management in Maize (Zea mays L.) - Wheat (Triticum aestivum L.) - Mungbean Cropping System. Int.J.Curr.Microbiol.App.Sci. 7(02): 1775-1785. doi: https://doi.org/10.20546/ijcmas.2018.702.215 